\title{
Using AHP and Spatial Analysis to Determine Water Surface Storage Suitability in Cambodia
}

\author{
Michael Ward ${ }^{1, *(1)}$, Cristina Poleacovschi ${ }^{1}$ and Michael Perez ${ }^{2}(\mathbb{C}$ \\ 1 Department of Civil, Construction, and Environmental Engineering, Iowa State University, \\ Ames, IA 50011, USA; poleacov@iastate.edu \\ 2 Department of Civil and Environmental Engineering, Auburn University, 238 Harbert Engineering Center, \\ Auburn, AL 36849, USA; map0032@auburn.edu \\ * Correspondence: mrward@iastate.edu
}

Citation: Ward, M.; Poleacovschi, C.; Perez, M. Using AHP and Spatial Analysis to Determine Water Surface Storage Suitability in Cambodia. Water 2021, 13, 367. https://doi.org/ $10.3390 /$ w13030367

Academic Editor: Luís Filipe Sanches Fernandes

Received: 21 December 2020

Accepted: 26 January 2021

Published: 31 January 2021

Publisher's Note: MDPI stays neutral with regard to jurisdictional claims in published maps and institutional affiliations.

Copyright: (c) 2021 by the authors. Licensee MDPI, Basel, Switzerland. This article is an open access article distributed under the terms and conditions of the Creative Commons Attribution (CC BY) license (https:// creativecommons.org/licenses/by/ $4.0 /)$.

\begin{abstract}
Cambodia suffers from devastating droughts in the dry season and floods in the wet season. These events' impacts are further amplified by ineffective water resources infrastructure that cannot retain water during the dry season. Water harvesting (the collection and management of floodwater or rainwater runoff to increase water supply for domestic and agricultural use) is an approach that could improve Cambodia's resiliency against droughts and floods. Despite the known benefits of water harvesting, there are currently few studies on water harvesting suitability in Cambodia. This research argues that suitable water harvesting sites can be identified by combining various expertise and evaluating hydrologic site conditions. Thirty-one local and USA water infrastructure experts made pairwise comparisons between essential engineering criteria: soil drainage, geologic porosity, precipitation, land cover, and slope. Then, model weights were calculated based on the comparisons. Using the model weights, a water harvesting suitability model showed that $19 \%$ of Cambodian land has high suitability, and about $13 \%$ of the land has the best suitability. This water harvesting model can help guide future water infrastructure projects to improve climate resiliency by identifying suitable sites for water harvesting reservoirs.
\end{abstract}

Keywords: water harvesting; water resources; disaster management; flooding; drought

\section{Introduction}

Cambodia suffers from devastating droughts during the dry season (November to April) and floods in the wet season (May to October) [1]. These disaster events adversely affect many Cambodian people's livelihoods and cause over 70,000 internal displacements annually [2-4]. Alarmingly, these disasters are only expected to worsen as Cambodia's precipitation patterns change with the global climate [5]. Alleviating these impacts has proven to be a multi-faceted challenge for the Cambodian government. For instance, inadequate water resource infrastructure, such as irrigation schemes, exacerbates effects by not effectively storing surface water. Irrigation schemes include canals and pipes used to supply water to cropland and communities. Many of these systems were implemented under the Khmer Rouge regime (1975-1979) with little regard to hydrological and geographic site conditions [1,3-5]. One study estimated that only around 6\% of Cambodia's 2525 irrigation schemes are fully functioning, with the rest either partially working or not functioning at all [4].

This work seeks to promote Cambodia's surface water supply and management through a water harvesting suitability study. Water harvesting entails collecting and managing floodwater or rainwater runoff to increase water availability for domestic and agricultural use and ecosystem sustenance [6]. In this context, water harvesting could improve the irrigation schemes' surface storage water capabilities by constructing surface water-harvesting reservoirs. Surface water harvesting reservoirs capture runoff from precipitation and floodwater from nearby water bodies. These reservoirs aim to store excess water for domestic and agricultural 
water supply and flood protection [6,7]. This approach has successfully alleviated droughts and floods in countries such as Thailand, India, Jordan, and Guatemala. [8-13]. This approach could be an appropriate solution as Cambodia has a demonstrated water harvesting history using reservoirs. Located in the Siem Reap province, the West Baray of Angkor is a large humanmade water harvesting reservoir built in the eleventh century $(7.8 \mathrm{~km} \times 2.1 \mathrm{~km} \times 4 \mathrm{~m})(4.9 \mathrm{mi}$, $0.6 \mathrm{mi}, 13.1 \mathrm{ft}$ ). It can store up to 53 million $\mathrm{m}^{3}$ (14 billion gallons) of water during Cambodia's dry season. The reservoir is fed by the Siem Reap River and from direct precipitation. Today, the Baray is still used to irrigate nearby farms and control flooding [14-16]. This Baray's importance suggests that water harvesting is a practical approach to improving Cambodia's water resources infrastructure.

Despite the demonstrated importance of water harvesting in Cambodia and worldwide, there are currently few studies on surface water storage and water harvesting in Cambodia [16]. Current studies mainly focus on the performance of existing systems, and there is a need to understand better where new systems could be implemented [17]. This research seeks to identify candidate sites in Cambodia that could be suitable for water harvesting. To address this objective, this research uses a combination of geospatial analysis and analytical hierarchy process (AHP) to develop a model to identify suitable water harvesting sites. AHP aims to combine the opinions of multiple experts to create a single cohesive decision model. This method entails a three-step process involving decomposing the problem into different criteria, prioritizing the criteria's importance, and then synthesizing the data into a suitability model. This study decomposed water harvesting suitability into five essential criteria: slope, land use, precipitation patterns, soil drainage, and geologic porosity $[7,10,18]$. This integration of Geographical Information Systems (GIS) and AHP has been widely used in studies related to natural and environmental decision making $[8,9,18-20]$. Despite the widespread use, this approach to determining water harvesting suitability has not been used in Cambodia. This research constructs a model that can identify highly suitable water retention sites through these pairwise comparisons.

\section{Literature Review}

\subsection{Water Harvesting Reservoirs}

Prior water harvesting studies have focused on evaluating the benefits of water harvesting reservoirs by assessing essential impacts such as water quality, water availability, social acceptance, and cost-benefit analyses. For example, a study of a rehabilitated water reservoir in Can Tho, Vietnam, showed that the reservoir improved the landscape's aesthetics, reduced flood inundation, and improved the watershed's drainage. In particular, the study estimated that the rehabilitated water reservoir could reduce the number of flooded areas by $40 \%$ [11]. In addition, studies in Cambodia have shown that the Barays at Angkor have improved residents' quality of life in the Siem Reap province by preventing floods, supplying water during drought months, providing fishing grounds, and promoting tourism [21]. For example, local fishers each catch at least $3 \mathrm{~kg}(6.6 \mathrm{lbs})$ of fish daily from the Baray $[16,21,22]$. These studies have shown that water harvesting reservoirs can improve water storage, flood protection, and its residents' quality of life. It is essential to expand this approach to disaster-prone and water-scarce areas [6,11].

The literature has also focused on identifying suitable sites for implementing water harvesting reservoirs because of the demonstrated benefits $[6,8,10,11]$. However, identifying suitable water harvesting sites can be challenging because of the different engineering criteria required to operate a water harvesting reservoir [6]. In addition, engineering criteria are often site-specific, making it challenging to infer findings from other studies. Thus, when building suitability models, the engineering criteria need to be appropriately weighted to reflect their importance in the study [6,7]. Many studies use a combination of AHP and spatial analysis to overcome these challenges. AHP is frequently used to convert empirical expert opinions into tangential numerical values, allowing them to be easily processed and compared. Because AHP can convert empirical data into mathematical models, many researchers choose to use it over other decision modeling techniques [23]. 
Thus, AHP allows researchers to effectively consult multiple experts to determine how crucial different engineering criteria are for the local context.

When using AHP, these studies first decomposed the goal of finding suitable sites into engineering criteria that could be compared against one another. For example, studies in Jordan, Thailand, and India broke water harvesting suitability into criteria such as slope gradient, annual precipitation, geologic porosity, land use, and soil drainage $[6,8,10,11]$. Then, local water infrastructure experts were asked to weigh engineering criteria by comparing the criteria against one another through pairwise comparisons. Finally, the expert comparisons were combined with spatial data to create a site-specific GIS map showing where suitable harvesting water sites were. These studies then further verified their constructed models with field visits and follow-up consultations with local experts $[8,10]$. For example, studies in Thailand have identified suitable sites for water harvesting, and the country is now piloting water harvesting methods to improve its climate resiliency [24].

\subsection{Water Harvesting in Cambodia}

There have been few studies on water resources and water harvesting in Cambodia $[4,5]$. Studies on Cambodia's water resources have focused mainly on the governance and performance of existing water systems [3,4,25]. Mang conducted a comprehensive evaluation of Cambodia's new Water Law, which sought to improve Cambodia's water resources management and governance [3]. As part of this law, Cambodia's government developed community-led water organizations to manage irrigation schemes. Sam and Shinogi [25] and Asthana [1] evaluated these community-led water committees. They found that engaging local communities and aligning irrigation improvements with local capacity were vital to improving water resource infrastructure functionality. However, Sithirith [4] concluded that Cambodia's water governance is too weak and fragmented to support these local groups. The current structure of water governance in Cambodia needs to be reworked. Further, Sithirith also found that inadequate water resources infrastructure made it more challenging to effectively manage irrigation schemes [4].

Despite this need to improve water resources infrastructure across the country, few studies have evaluated surface water storage sites, such as water harvesting reservoirs. Instead, previous studies have primarily focused on the performance and benefits of existing reservoirs and systems $[16,17,22,26]$. For example, Someth et al. [16] conducted a water balance on the West Baray. Someth showed that the Baray effectively stores surface water for flood protection and drought mitigation and that similar systems could be used in other parts of Cambodia. Similarly, Räsänen et al. [26] showed that a series of reservoirs could significantly improve water supply in the Sesan river valley; however, he concluded that more multicriteria assessment work is needed to implement these systems successfully. Thus, these studies assert that more studies are necessary to sit and assess improvements to Cambodia's water resources infrastructure. This research seeks to address this assessment gap by evaluating relevant engineering criteria such as topography, annual precipitation, soil drainage, geologic porosity, and land use to identifying locations where new water harvesting reservoirs could be implemented. The goal of these reservoirs would be to improve domestic water supply and increase irrigation water supply.

\section{Study Area}

Cambodia is a relatively flat, riparian state of the Mekong River. The country's landscape is dominated by the Tonle Sap and Mekong River drainage basins, which comprise about $86 \%$ of the country's landmass. Inflows from the Mekong-Tonle system are estimated to be around 410 billion $\mathrm{m}^{3} /$ year (108 trillion gallons) [3,4,27]. In addition, Cambodia's climate is driven by tropical monsoons. The average annual precipitation in Cambodia is estimated to be between 1300 to $1900 \mathrm{~mm}$ ( 51 to 75 in.). Generally, 80\% of the annual rainfall occurs during the wet season from April to September [27]. Because of this abundance of water and flat-land, agriculture is widespread across Cambodia. Around half of Cambodia's 13.8 million population works in sustenance farming, with rice being the main crop [27]. 
Despite such prolific agriculture and water abundance, crop yields in Cambodia are low compared to neighboring countries, such as Vietnam [28]. This can partly be attributed to Cambodia's seasonal droughts and floods and a lack of functioning irrigation schemes [1]. The floods in the wet season often inundate crop-fields, while the droughts often result in significant crop failure [27]. Thus, there is a need to retain and reuse surface water.

\section{Methods}

This research follows the three phases of the AHP: decomposition, prioritization, and synthesis. Decomposition involved breaking the overarching goal of water harvesting suitability into five essential engineering criteria. Prioritization entailed surveying water resources experts on how to weight the various criteria. Synthesis took the prioritized criteria and combined them into a composite decision model [23,29]. These steps are further described in the below sections.

\subsection{Phase 1-Decomposition}

Decomposition entails breaking a complex objective into a hierarchy of interrelated criteria. The criteria are arranged in a hierarchical structure to chain all decision criteria from the top level down. The main aim of this study, suitable water harvesting sites, was broken into five main criteria: (1) soil drainage, (2) geologic porosity, (3) annual precipitation, (4) slope, and (5) land cover $[8,10]$. These criteria were selected based upon water harvesting design guidelines and water harvesting studies, as noted in the literature review $[6,7]$. The spatial data associated with the main criteria were collected from open-source secondary databases, as detailed in the following sections. All secondary data used in this manuscript is publically available and free to use for educational and non-commercial purposes. Table 1 details the resolution and source for each dataset used in this manuscript.

Table 1. Manuscript spatial data resolution and source.

\begin{tabular}{|c|c|c|c|c|}
\hline $\begin{array}{l}\text { Engineering } \\
\text { Criterion }\end{array}$ & $\begin{array}{c}\text { Metric } \\
\text { Resolution }\end{array}$ & $\begin{array}{l}\text { Imperial } \\
\text { Resolution }\end{array}$ & Database Name & Database Location \\
\hline Soil Drainage [30] & $1000 \mathrm{~m} \times 1000 \mathrm{~m}$ & $3280 \mathrm{ft} \times 3280 \mathrm{ft}$ & $\begin{array}{l}\text { Harmonized World } \\
\text { Soil Database }\end{array}$ & $\begin{array}{l}\text { Food and Agriculture } \\
\text { Organization of the United } \\
\text { Nations-Rome, Italy }\end{array}$ \\
\hline Geologic Porosity [31] & $15 \mathrm{~m} \times 15 \mathrm{~m}$ & $50 \mathrm{ft} \times 50 \mathrm{ft}$ & $\begin{array}{c}\text { GLobal HYdrodeology } \\
\text { MaPS }\end{array}$ & $\begin{array}{c}\text { University of } \\
\text { Victoria-Victoria, British } \\
\text { Columbia, Canada }\end{array}$ \\
\hline Annual Precipitation [32] & $500 \mathrm{~m} \times 500 \mathrm{~m}$ & $1640 \mathrm{ft} \times 1640 \mathrm{ft}$ & $\begin{array}{l}\text { Climate Hazards Group } \\
\text { InfraRed Precipitation } \\
\text { with Station data }\end{array}$ & $\begin{array}{c}\text { University of California Santa } \\
\text { Barbara-Santa Barbara, } \\
\text { California, USA }\end{array}$ \\
\hline Slope [33] & $90 \mathrm{~m} \times 90 \mathrm{~m}$ & $295 \mathrm{ft} \times 295 \mathrm{ft}$ & $\begin{array}{c}\text { Geographical Relief } \\
\text { of Cambodia }\end{array}$ & $\begin{array}{l}\text { Open Development } \\
\text { Cambodia-Phnom Penh, } \\
\text { Cambodia }\end{array}$ \\
\hline Land Cover [34] & $250 \mathrm{~m} \times 250 \mathrm{~m}$ & $820 \mathrm{ft} \times 820 \mathrm{ft}$ & $\begin{array}{l}\text { Regional Land Cover } \\
\text { Monitoring System }\end{array}$ & $\begin{array}{l}\text { Asian Disaster Preparedness } \\
\text { Center-Yangon, Myanmar }\end{array}$ \\
\hline $\begin{array}{l}\text { Control } \\
\text { Criterion }\end{array}$ & $\begin{array}{c}\text { Metric } \\
\text { Resolution }\end{array}$ & $\begin{array}{l}\text { Imperial } \\
\text { Resolution }\end{array}$ & Database Name & Database Location \\
\hline $\begin{array}{c}\text { Explosion Contamination } \\
\text { Zone [35] }\end{array}$ & $\mathrm{N} / \mathrm{A}$ & $\mathrm{N} / \mathrm{A}$ & $\begin{array}{l}\text { Baseline Survey on } \\
\text { Mine/ERW }\end{array}$ & $\begin{array}{c}\text { Open Development } \\
\text { Cambodia-Phnom Penh, } \\
\text { Cambodia }\end{array}$ \\
\hline Protected Areas [36] & $\mathrm{N} / \mathrm{A}$ & $\mathrm{N} / \mathrm{A}$ & $\begin{array}{l}\text { Natural Protected } \\
\text { Areas in Cambodia }\end{array}$ & $\begin{array}{c}\text { Open Development } \\
\text { Cambodia-Phnom Penh, } \\
\text { Cambodia }\end{array}$ \\
\hline $\begin{array}{l}\text { Watershed } \\
\text { Criterion }\end{array}$ & $\begin{array}{c}\text { Metric } \\
\text { Resolution }\end{array}$ & $\begin{array}{l}\text { Imperial } \\
\text { Resolution }\end{array}$ & Database Name & Database Location \\
\hline Watersheds [37] & $\mathrm{N} / \mathrm{A}$ & $\mathrm{N} / \mathrm{A}$ & HydroSHEDS & $\begin{array}{c}\text { World Wildlife } \\
\text { Fund-Washington, District of } \\
\text { Columbia, USA }\end{array}$ \\
\hline Curve Number [38] & $250 \mathrm{~m} \times 250 \mathrm{~m}$ & $820 \mathrm{ft} \times 820 \mathrm{ft}$ & Global Curve Number & $\begin{array}{l}\text { American University of } \\
\text { Beirut-Beirut, Lebanon }\end{array}$ \\
\hline
\end{tabular}




\subsubsection{Soil Drainage}

Soil drainage refers to how well a soil can retain water above the surface. As the goal of water harvesting reservoirs is to store water above the surface, soils with poor drainage are generally preferred $[7,39]$. To determine soil drainage properties in Cambodia, the United Nations Food and Agriculture Organization's (FAO) Harmonized World Soil Database (HWSD) was used. The HWSD is a global survey of soil properties, including drainage classes for various soil types. These drainage classes include ordinal levels that range from "very rapidly drained" to "very poorly drained" [30,40]. Figure 1 shows the soil drainage map for Cambodia.

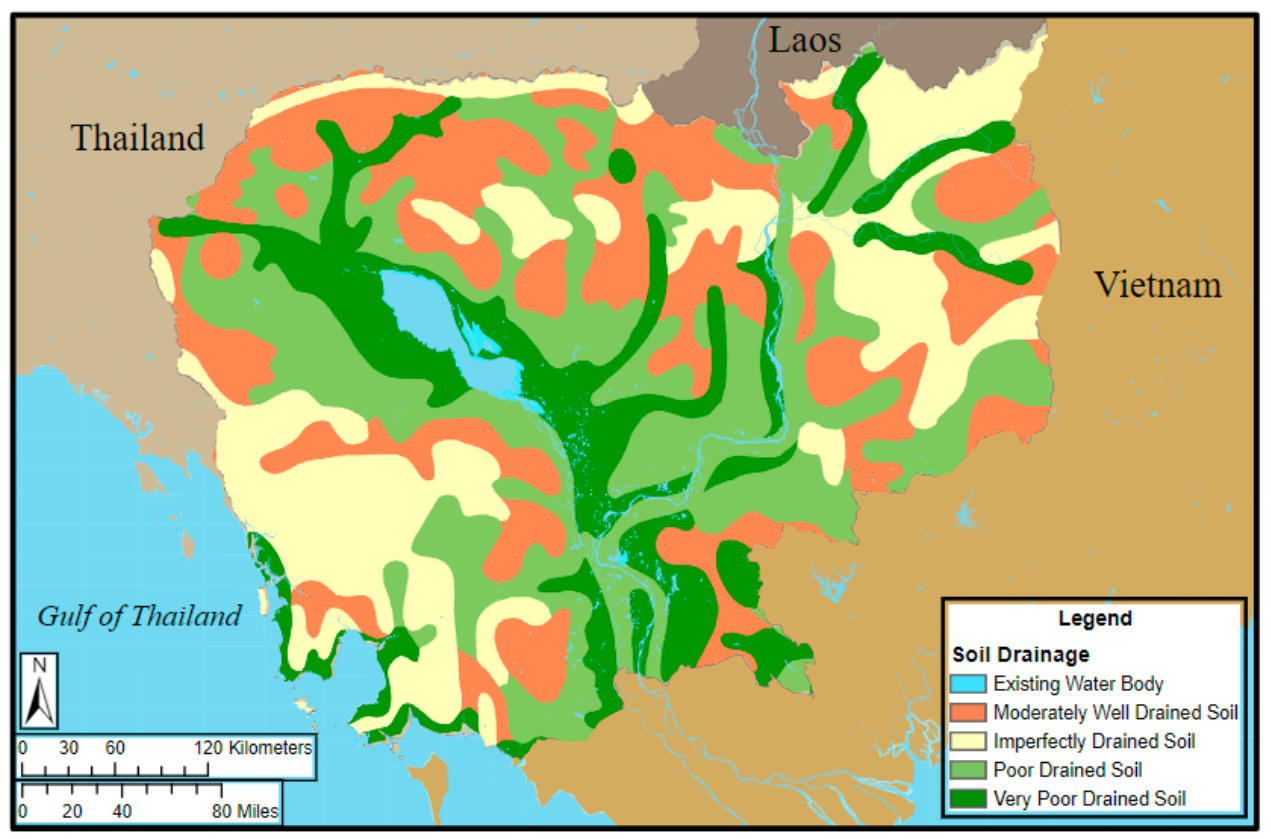

Figure 1. Soil drainage map of Cambodia. Adapted from FAO's [30] Harmonized World Soil Database.

\subsubsection{Geologic Porosity}

Geologic porosity indicates a ratio of void space present in a geologic formation. The more porous a formation is, the less suitable it is for retaining water above the surface [7,31]. This study used the GLobal HYdrodeology MaPS (GLHYMPS) of permeability and porosity to determine porosity in Cambodia. GLHYYMPS is a global database of porosity compiled by synthesizing existing databases on porosity. The database presents porosity as a percentage of how many voids are present in the geology [31]. Figure 2 shows a geologic porosity map for Cambodia. The database estimated six porosity groups ranging from $1 \%$ to $27 \%$. This criterion was included as the soil drainage map only estimated drainage up to $100 \mathrm{~cm}$ (40 in.) below the surface [30]. The GLHYYMPS database estimates drainage up to $100 \mathrm{~m}$ (328 ft) below the surface, which provides a more accurate understanding of deeper subsurface drainage patterns. Understanding deeper subsurface patterns is important to the effective operation of earthen reservoirs [41].

\subsubsection{Precipitation}

Precipitation refers to how annual rainfall is spatially distributed across a geographic region. Locations that receive more precipitation are more suitable for implementing water harvesting reservoirs; however, too much or too little precipitation can damage water harvesting reservoirs [6]. For example, too much precipitation can scour a reservoir and cause it to fail. This study relied on the Climate Hazards Infrared Precipitation with Stations (CHIRPS) to determine Cambodia's precipitation. CHIRPS is a global database that tracks precipitation patterns around the world. This research used the annual average precipitation (reported in mm) measured between 2001 and 2014 [32,42]. Precipitation depths 
were reclassified into six sub-criteria using Jenk's natural break method: (1) 924-1522 mm (36.4-59.2"), (2) 1522-1921 mm (59.2"-75.6"), (3) 1921-2348mm (75.6"-94"), (4) 2348-2861 $\mathrm{mm}\left(94^{\prime \prime}-116^{\prime \prime}\right),(5)$ 2861-3545 mm (116"-139.6"), and (6) 3545-4557 mm (139.6"-179.4") [43]. Jenk's method is commonly used when classifying geospatial data. It minimizes the average deviation of a data cluster while maximizing each clusters' deviation from the other clusters' means. This approach effectively identifies clusters in the data while uniformly distributing error across the data. This approach was suitable for the criterion category, as there was a wide variety of precipitation data, and only six groups were created [43]. Figure 3 shows the annual precipitation map for Cambodia.

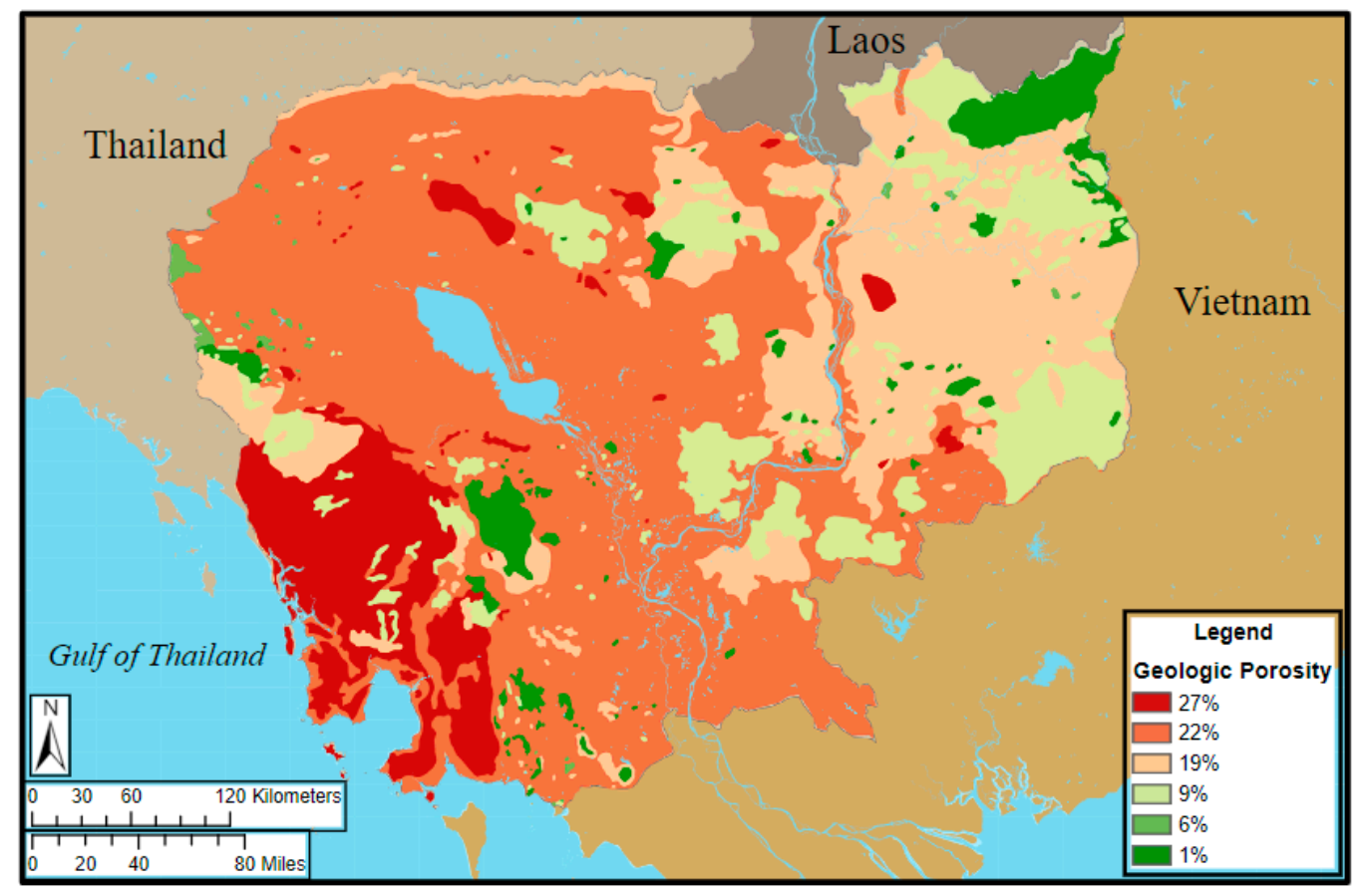

Figure 2. Geologic porosity map of Cambodia. Adapted from Gleeson's et al. [31] GLMYPHS database.

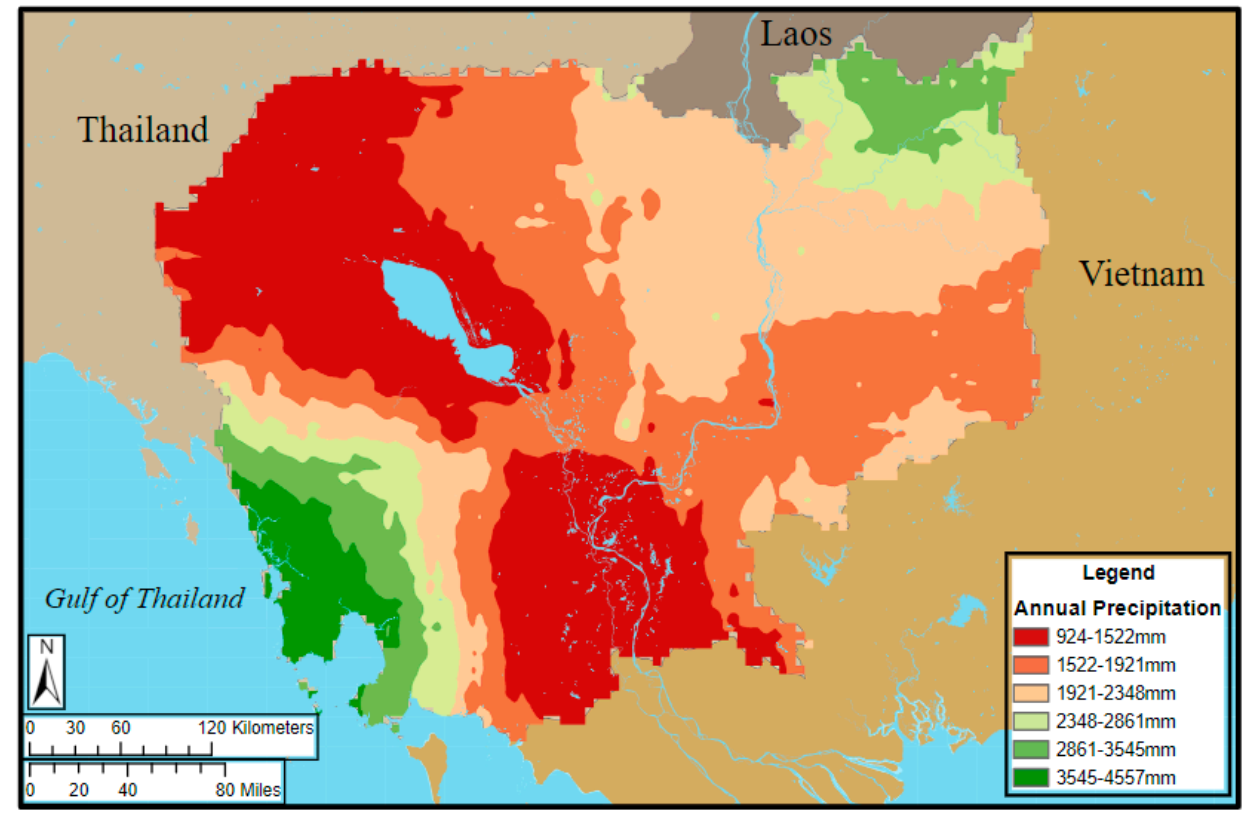

Figure 3. Annual precipitation map of Cambodia. Adapted from UCSB's [32] CHIRPS database. 


\subsubsection{Slope}

Steep topographies are not ideal for water retention, as steep areas require large amounts of earthwork. Conversely, flat areas are not ideal as a gentle slope is needed to convey water effectively. Thus, a $2-10 \%$ slope is recommended for these structures $[7,10]$. Existing slopes were determined from a georelief map of Cambodia using GIS's slope algorithm. This entailed using cubic interpolation to calculate the slope between the cells in the georelief map. The georelief map was adapted from the Atlas of Cambodia and was originally mapped by the U.S. Geologic Survey [33]. Slopes were reclassified into six subcriteria using Jenk's natural break method: (1) $24.80 \%+$, (2) $16.4 \%-24.8 \%$, (3) $10.2 \%-16.4 \%$, (4) $5.1 \%-10.2 \%$, (5) $1.62 \%-5.1 \%$, (6) $0-1.62$. This approach was suitable for the slope criterion as there was a wide variety in slope data and only six groups were created [43]. Figure 4 shows a topographic map of Cambodia.

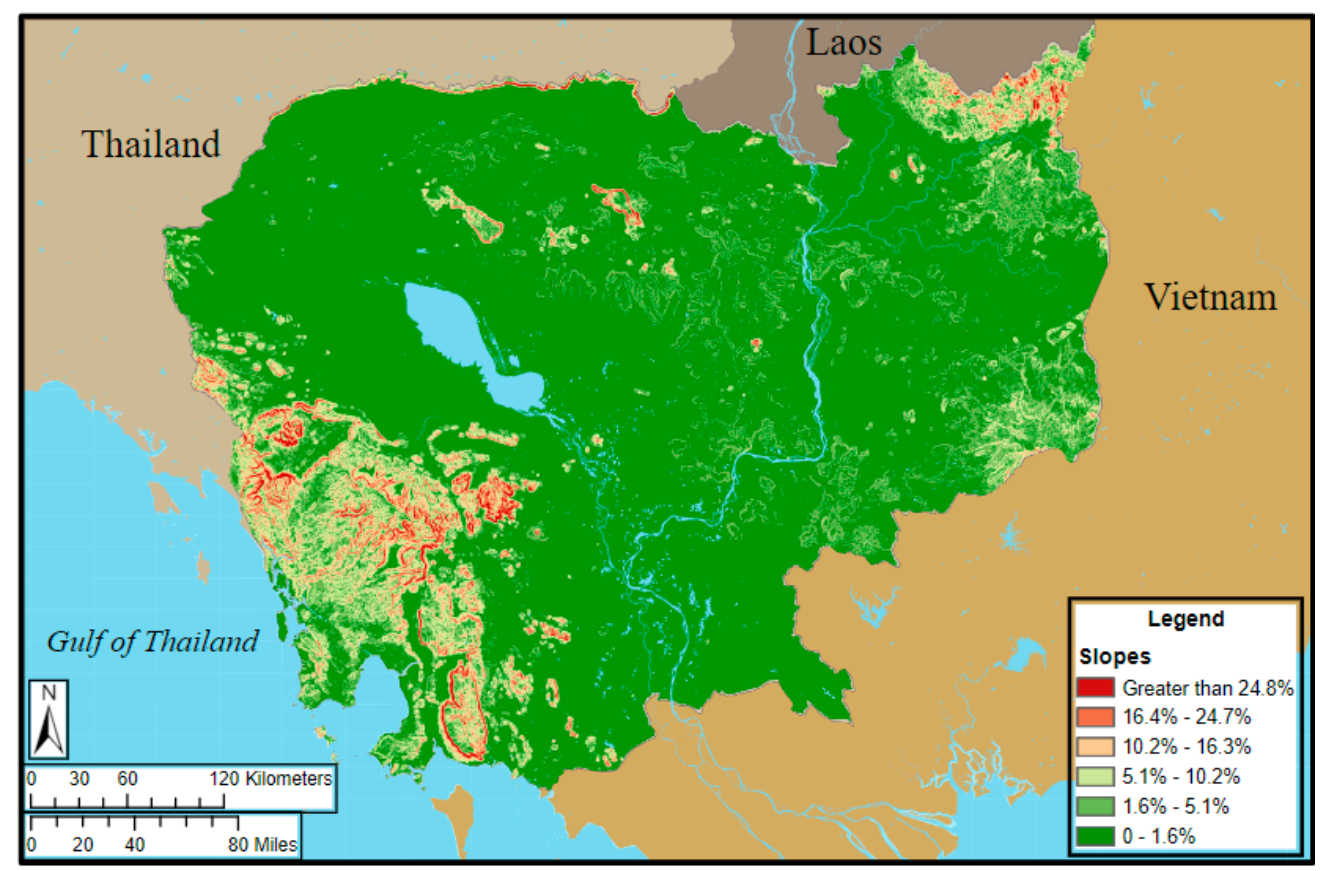

Figure 4. Calculated slope map of Cambodia. Adapted from Open Development Cambodia's [33] georelief map.

\subsubsection{Land Cover}

Land cover refers to how land is being used in a particular area. Constructing water harvesting reservoirs could require extensive earthwork. Thus, urban areas and forested areas are less suitable than open areas. Land cover was extracted from the Regional Land Cover Monitoring System developed by SERVIR-Mekong [34]. Land cover in Cambodia was reclassified into six sub-criteria, including existing water bodies, wetlands, forests, urban, cropland, and barren. To create a more conservative model, rice paddies were included under croplands instead of wetlands. While rice paddies retain water during the wet season, most run dry during the dry season [44]. Figure 5 shows a land cover map of Cambodia. 


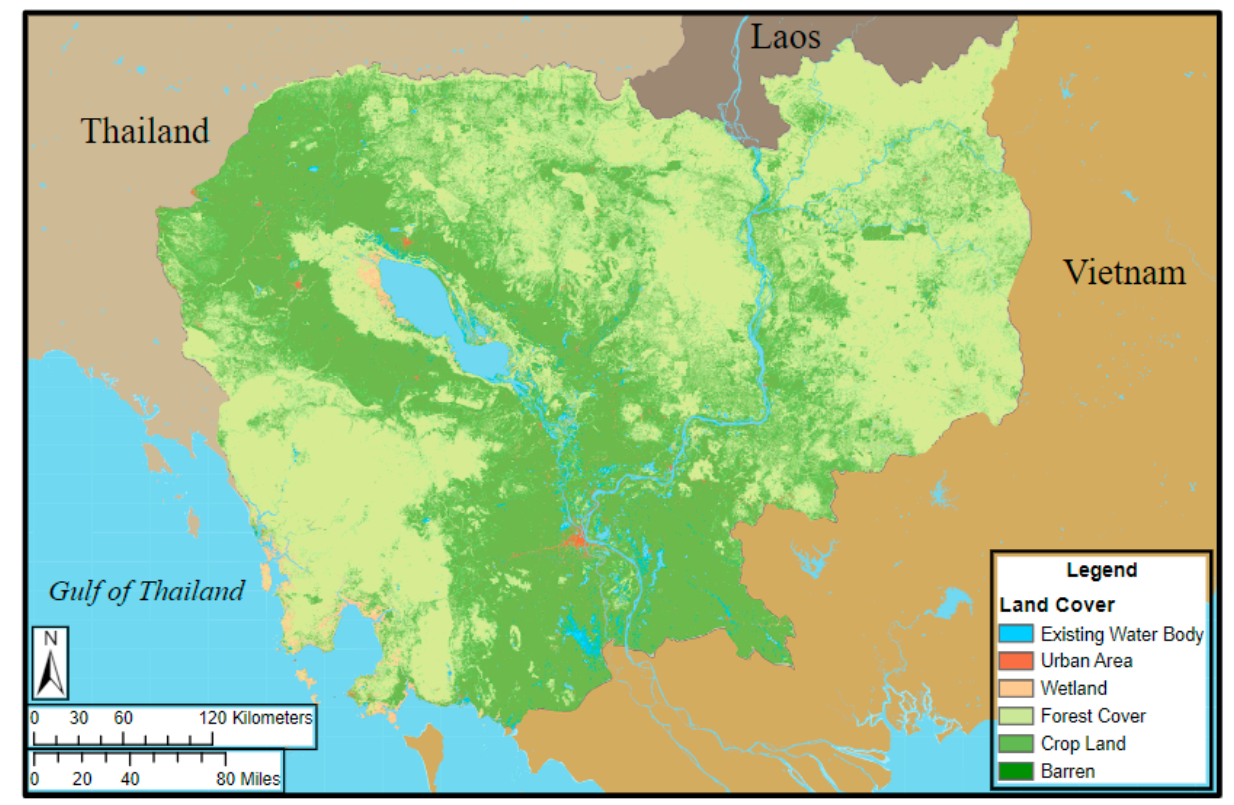

Figure 5. Land cover map of Cambodia. Adapted from ADPC's [34] land use database.

\subsection{Phase 2-Prioritization}

Prioritization calculates the criteria' importance through expert opinions and a pairwise comparison matrix. Comparisons between criteria are made on a numerical scale ranging from 1 to 9 where " 1 " indicates the criteria are equally important, and " 9 " indicates one criterion is significantly more important than another. These pairwise comparisons assign weighted scores, known as prioritization values, to each criterion [23].

The team collected data by surveying experts in Cambodia and the United States. Similar to other studies, experts surveyed in this study had to meet three criteria [18]:

(1) actively working in the field of civil engineering, water resources, geology, hydrogeology, hydrology, or environmental sciences,

(2) have at least five years of work experience in their field,

(3) Possess a college degree or higher.

Because of these criteria, experts were selected for this study using purposeful sampling and snowball sampling. Experts in Cambodia were identified through a partnership with local non-governmental organizations. Experts in the United States were identified through personal connections, government directories, and university directories. Before survey distribution, the survey was reviewed and piloted for clarity by engineering and environmental experts in the U.S. and Cambodia. The survey and data collection procedures were reviewed for ethical compliance by the Institutional Review Board (IRB) at Iowa State University (IRB Number 19-255). Surveys were distributed electronically to the experts using Qualtrics, an online survey platform. To ensure valid responses, a participant had to make all the survey comparisons. Experts contacted the researchers through phone or e-mail if anything on the survey was not clear.

The survey first asked for basic information regarding the participant's expertise, such as job title, job duties, and years of work experience. Then, the participants made pairwise comparisons between the main criteria. For example, the participants were asked questions such as "On a scale from -9 to 9 , how much more important is geologic porosity than slope gradient". Next, the participants ranked the sub-criteria associated with each of the main participants. For example, this included questions such as "From 1 to 6, rank how important the following land covers are for water harvesting: Wetlands, Forest, Crop Land, Urban Development, Barren Land, and Existing Water Bodies". Data from the expert surveys were then cleaned and organized in a spreadsheet. A comparison matrix was created, showing how each expert scored the comparisons between the main criteria. 
In the comparison matrix, geometric mean was used to assign a prioritization value to the expert opinions. The geometric mean method was used because it accounts for both the meaning of judgments and priorities in pairwise comparison models [45]. Geometric mean was calculated using Equation (1), where $\Pi=$ the geometric mean, $n=$ number of responses, and $a=$ the value assigned by each expert.

$$
\Pi=\sqrt[n]{a_{1} \times a_{2} \times a_{3} \cdots \cdots a_{n}}
$$

The sub-criteria's prioritization values were calculated using the arithmetic mean of the expert responses and then ranking the responses from one to six. After prioritization values were calculated for the main criteria, an inverse comparison matrix was created, and the sum of scores for each column was calculated. Equation (2) was used to obtain the weight for each criterion where $w_{i}=$ the criteria's weight, $x_{i}=$ sum of scores for each criterion in the inverse matrix, and $x_{n}=$ sum of all scores obtained for each criterion [23].

$$
w_{i}=\frac{x_{i}}{\sum x_{n}}
$$

The consistency ratio was calculated for the scoring matrix to account for subjectivity and inconsistencies associated with the scoring and weighting process. The consistency ratio is a concept introduced by Saatay and Vargas to account for the inconsistency in judgments [46]. The consistency ratio was calculated by dividing the same index's consistency index from a randomly generated comparison matrix. The consistency index was calculated using Equation (3), where $C I=$ the consistency index, $\lambda_{\text {max }}=$ the largest eigenvalue of the comparison matrix, and $n=$ the number of responses.

$$
C I=\frac{\lambda_{\max }-n}{n-1}
$$

The inconsistency in the judgments in considered acceptable if the calculated consistency ratio is below $10 \%$. If the consistency ratio was above $10 \%$, then the judgments are considered inconsistent [46].

\subsection{Phase 3-Synthesis}

Suitable water harvesting sites were identified using a weighted linear combination. The weighted linear combination was calculated using Equation (4), where $R_{i}$ is the overall suitability score for an area, $w_{n}$ is the criteria weight, and $r_{i n}$ is the associated sub-criteria score [47].

$$
R_{i}=\sum_{n} w_{i} r_{i n}
$$

Once suitability scores were calculated for each cell in the GIS model, the scores were classified into six categories using Jenk's natural break method. This approach was suitable for the scores as there was a wide variety in score data, and only six groups were created [43]. The higher the overall score, the more suitable the site was for water reservoirs. The score tiers are shown in Figure 6.

\subsection{Restricted Areas}

In addition to the engineering criteria, two overlays were added to show areas where work could be potentially restricted. Table 1 details the source and location of the data. According to the government, 35\% of Cambodia's land is considered restricted due to protected areas or the possible presence of unexploded ordinances. These constraints may not completely inhibit the construction of water harvesting reservoirs; however, special considerations and precautions would need to be taken. Future studies and projects would need to consult with the Government of Cambodia and local stakeholders to determine if water harvesting reservoirs would be appropriate in these locations. Protected zones include national parks, wildlife sanctuaries, protected landscapes, multiple-use land, natural 
heritage sites, Ramsar-wetland sites, and marine national parks [36]. The contamination areas show areas expected to still contain landmines and unexploded ordinance of war as of 2014. In 2010, the Cambodian Mine Action Center estimated between four to six million explosive ordinances still scattered throughout the country from the Khmer Rouge [35,48].

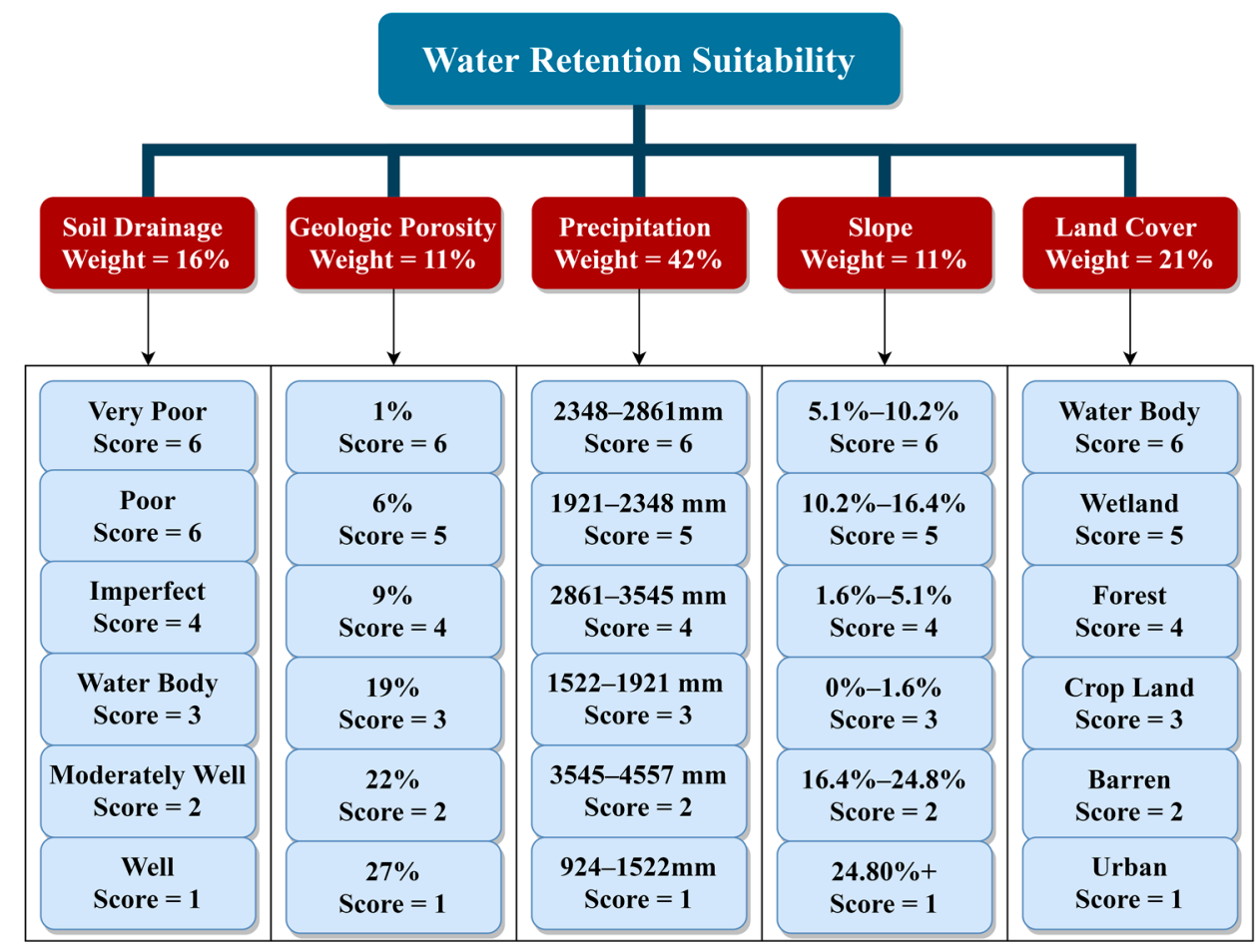

Figure 6. Water retention suitability hierarchy.

\subsection{Model Reliability}

A simple watershed model was created to roughly model potential storm inflows and test a suitable site's hydrologic performance, Stormwater depth and volume were calculated using the NRCS Curve Number Method. The NRCS method was selected as it is commonly used to assess stormwater flows in small watersheds [38,49]. A watershed was chosen by comparing our suitability model to the Hydrosheds database. Hydrosheds uses $90 \mathrm{~m} \times 90 \mathrm{~m}(295 \mathrm{ft} \times 295 \mathrm{ft})$ DEM data to delineate watersheds throughout the world [37]. An average watershed curve number was calculated using GCN250. GCN250 uses a $300 \mathrm{~m} \times 300 \mathrm{~m}(984 \mathrm{ft} \times 984 \mathrm{ft})$ land cover database and a $250 \mathrm{~m} \times 250 \mathrm{~m}(820 \mathrm{ft} \times 820 \mathrm{ft})$ soil database to calculate global curve numbers [38]. A 1 yr, 24 hr storm event was used to model common conditions that a community may see annually. Table 1 provides more detail on the location and source of the watershed data.

\section{Results and Discussion}

\subsection{AHP Model}

A total of 31 experts were surveyed for this study. This included nine experts from Cambodia and 22 from the USA. Table 2 shows the sample characteristics. Table 3 shows the comparison matrix generated from the surveys. The comparison matrix shows how each criterion ranked against one another. A score greater than one indicates that the criterion in the column is preferred to that in the row. For example, the score of 1.91 shows that "Annual Rainfall" is more important to water harvesting than "Land Cover". The score of 0.79 shows that "Geologic Porosity" is less important than "Slope Gradient". The consistency ratio calculated for the matrix was 0.01 ; thus, the matrix can be considered reliable. Figure 6 shows the hierarchy calculated from the comparison matrix and the sub-criteria's expert rankings. 
Table 2. Local and international expert sample characteristics.

\begin{tabular}{cc}
\hline Role & $n$ \\
\hline Project Manager & 5 \\
Academic & 16 \\
Engineer & 5 \\
Scientist & 5 \\
\hline
\end{tabular}

Table 3. Comparison matrix.

\begin{tabular}{ccccccc}
\hline Criteria & Geologic Porosity & Soil Drainage & Slope Gradient & Annual Rainfall & Land Cover & Weight \\
\hline Geologic & 1.00 & 0.97 & 0.79 & 0.22 & 0.48 & $11 \%$ \\
Porosity & 1.00 & 1.00 & 0.62 & 0.28 & 0.68 & $11 \%$ \\
Slope Gradient & 1.30 & 1.61 & 1.00 & 0.39 & 0.71 & $16 \%$ \\
Soil Drainage & 4.50 & 1.61 & 2.60 & 0.52 & 1.91 & $42 \%$ \\
Annual Rainfall & 2.10 & 1.48 & 1.40 & & & 1.00 \\
Land Cover & & & & & & \\
\hline
\end{tabular}

The AHP results show that precipitation was the most important criterion for water harvesting sites (weight $42 \%$ ). Annual precipitation was more important than the other criteria by a factor of two. This was expected as water harvesting reservoirs rely heavily on precipitation for their functionality [6,7]. The most essential precipitation ranges were 2348-2861 mm (94-116 in.) and 1921-2348 mm (59.2-75.6 in.) per year within the annual rainfall criteria. This is consistent with water harvesting guidelines that state too much precipitation $(>3000 \mathrm{~mm},>118 \mathrm{in}$.) can cause damage to water harvesting structures $[6,7]$ and too little precipitation ( $<1000 \mathrm{~mm},<40 \mathrm{in}$.), can cause stored water to evaporate faster than it is recharged [6].

The second most critical main criterion was land cover (21\%). Within this main criterion, water bodies and wetlands were the best land types to build water harvesting structures. This is likely because wetlands and water bodies already have some floodwater harvesting capabilities that make constructing floodwater harvesting reservoirs easier $[6,7]$. Urban areas and cropland were considered less suitable. This is likely because building in urban areas or on cropland would entail displacing communities and businesses.

Soil drainage was the third most important criterion (16\%). Very poor and poor draining soils were determined to be the best soils. Very poor and poorly drained soils effectively keep water above the ground to be collected and stored for domestic and agricultural use. While these soils were determined to be the best, they may clog due to long-term siltation [30]. Well drained soils were considered the worst soils. This is likely because well-drained soils fail to retain water above the surface [30].

Geologic porosity and slope gradient were tied for the fourth most critical main criterion $(11 \%)$. A total of $1 \%$ geologic porosity was determined to be the best porosity sub-criteria for water harvesting reservoirs. Similar to soil drainage, a poorly drained rock formation can help keep water above the surface [6,7,31]. Likewise, 27\% of geologic porosity was considered the worst as these rock formations are too porous to keep water above the surface effectively.

For slope, 5.1-10.2\% was the best slope range. This is consistent with water harvesting guidelines suggesting that $2-10 \%$ is the ideal slope range for constructing water harvesting infrastructure [6,7]. This is because slopes that are too flat $(<2 \%)$ make it challenging to convey water. Slopes that are too steep $(15 \%+)$ require extensive earthwork and are expensive to implement.

\subsection{GIS Model}

Figure 7 shows the GIS suitability model for water harvesting in Cambodia. Figure 8 shows the distribution of suitable land from the model. Based on Figure 7, 19\% of Cambodian land has high suitability, and about $13 \%$ of the land has the best suitability. These 
findings were expected as Cambodia is a relatively small and flat country with a reasonably uniform landscape [27]. There are several suitable sites near the Mekong and Tonle Sap Rivers' confluence in Kampong Thom and Kampong Cham provinces. As these provinces are situated between Cambodia's two largest rivers, they have significant flooding problems in the wet seasons. Furthermore, these two areas have high agricultural activity, which suffers from droughts and floods [25]. Thus, these areas could benefit from water harvesting. In addition, several suitable sites were up in the Stung Treng province near the Laos border. Like Kampong Cham and Kampong Thom, Stung Treng Province suffers from severe floods because of its proximity to the Mekong River. In addition, this helps support prior studies in Stung Treng that have shown that the province could benefit from water harvesting reservoirs [26].

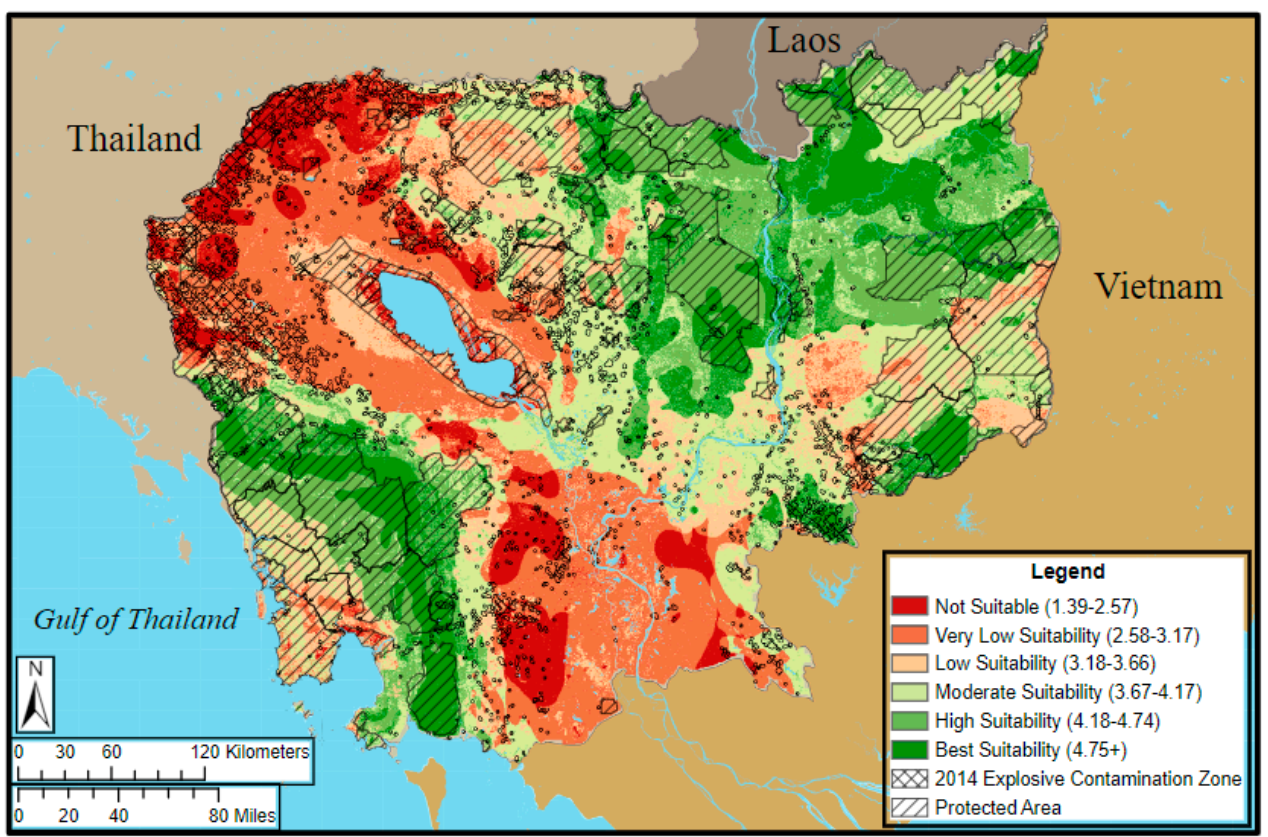

Figure 7. Cambodia water harvesting suitability.

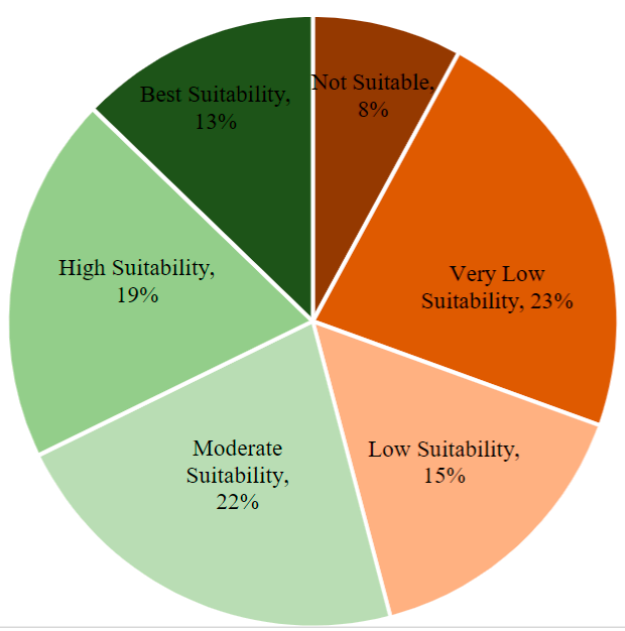

Figure 8. Distribution of suitable land in Cambodia for water harvesting.

A total of $46 \%$ of Cambodian land was classified as low suitable or lower. This mostly included the central plains of the country. While this region could benefit from water harvesting, the landscape is too flat or does not have enough precipitation. Furthermore, this area has a lot of agricultural activity, and these structures could displace farms and 
homes [27]. These areas also include many large urban centers (Phnom Penh, Siem Reap town, Battambang town). While these large urban centers could benefit from water harvesting reservoirs, each of these urban centers would need to be analyzed at a finer scale to determine suitable sites. For example, Phnom Penh, Cambodia's capital and largest city, regularly floods during the wet season. This issue has been compounded by the filling-in of lakes and natural waterways around the city to provide more land for development. Filling in these lakes has drastically changed Phnom Penh's watershed and flood resiliency; thus, there is an urgent need to identify sites where water can be harvested and retained [50,51].

\subsection{Simple Watershed Model}

A highly suitable watershed was identified in Northeastern Cambodia for a watershed analysis. Figure 9 shows the location of the watershed. Table 4 shows the watershed characteristics and calculated outflows. The team did not find design-storm data for this region of Cambodia, so precipitation data were used from Siem Reap, an area with similar rainfall [52].

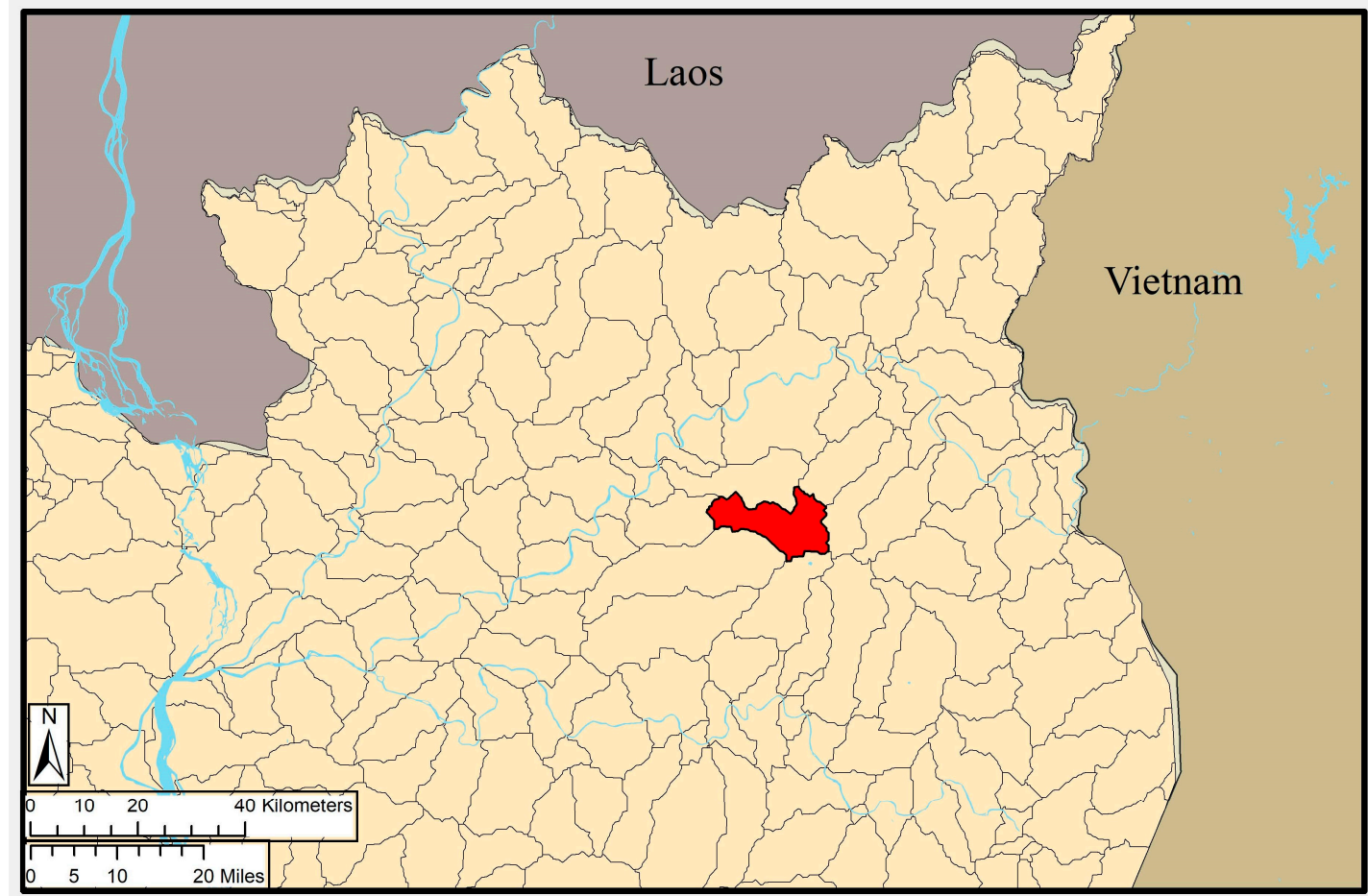

Figure 9. Identified watershed and potential reservoir location. Location highlighted in red. Adapted from WWF's [37] HydroSHEDs database.

Table 4. Watershed characteristics.

\begin{tabular}{ccc}
\hline Characteristics & Metric Units & Imperial Units \\
\hline Watershed Suitability Score & 4.70 & 4.70 \\
Watershed Area & $163 \mathrm{sq}-\mathrm{km}$ & $63 \mathrm{sq}-\mathrm{miles}$ \\
Watershed Slope & $2.0 \%$ & $2.0 \%$ \\
Watershed Curve Number & 80 & 80 \\
1-yr 24-hr Precipitation & $8.1 \mathrm{~cm}$ & $3.2 \mathrm{in}$ \\
Calculated Stormwater Depth & $3.5 \mathrm{~cm}$ & $1.4 \mathrm{in}$ \\
Calculated Stormwater & $5,674,000 \mathrm{~m}^{3}$ & 4600 acre-ft \\
Volume & & \\
\hline
\end{tabular}


The simplified watershed model showed that the suitable watershed could potentially produce 5,674,000 $\mathrm{m}^{3}$ (4600 acre-ft) of stormwater runoff in a $1 \mathrm{yr}, 24 \mathrm{hr}$ storm event. Therefore, the watershed is capable of supporting water harvesting reservoirs.

\subsection{Limitations}

The suitability model was created strictly using engineering criteria. Thus, the suitability model should not be considered an absolute model; instead, it suggests there are suitable sites for water harvesting in Cambodia that should be investigated further. For instance, the suitability does not consider socioeconomic parameters and community priorities. Prior studies have shown these are also key to the operation and management of Cambodia's water resources and must be developed in conjunction with any infrastructure improvements $[3,4,25]$. This research did not consider current events and changes within the greater Mekong Watershed. For example, water quality and quantity have been detrimentally affected by increased damming in China and Laos, resulting in less floodwater, water transport, and water transport $[26,53]$. These changes could influence the suitability of water harvesting in Cambodia. Further, this work did not consider the similar impacts large-scale water harvesting could have on the Mekong watershed.

In addition, this research relied on coarse spatial databases. Coarse databases were used because there is a lack of countrywide hydrologic and spatial data in Cambodia, partly due to the Khmer Rouge regime [3,4]. These databases are approximate and may not entirely reflect the local realities. For example, the classification of rice paddies as "cropland" may be underestimating the surface water storage suitability of certain areas. However regarding the data resolution, past studies suggest that the spatial data resolution may be acceptable for a suitability model of this scale [54,55].

In addition, this model does not include the effects of groundwater on surface water storage. While there has been limited work on groundwater in Cambodia, these studies suggest that the groundwater table may be deep enough not to influence surface water storage [28]. Furthermore, the explosive containment zone map is over 5 years old, and the Cambodian government has been actively removing explosive ordinance from the landscape. Therefore, there might be fewer explosive contamination zones are than shown in the model. Despite these limitations, this is the first model of its kind for Cambodia, to the author's knowledge, and it is important to develop such a model.

There are a few limitations to consider when analyzing the watershed model. First, the model was done at a macro-scale and did not account for the watershed's detailed topography. Watershed parameters were averaged across the watershed instead of evaluating all of the unique parameters present in the watershed. This means that the calculated stormwater volume may be spread across multiple outlets throughout the watershed. The analysis should not be used to design a structure, and a more detailed hydrologic will ultimately be needed. Further, the watershed model does not account for any surface water features that may already be present.

\subsection{Contributions}

This work has both critical practical and theoretical contributions. This model can practically help Cambodian officials identify sites where water harvesting reservoirs can be constructed. This is an essential contribution because droughts and floods are expected to worsen, and there are currently few studies evaluating where infrastructure can be implemented to mitigate these impacts $[16,26]$. Constructing such reservoirs can improve surface water storage and community resiliency. The results helped bridge this gap by showing that the disaster-prone provinces of Kampong Cham, Kampong Thom, and Strung Tren could be suitable areas for constructing water harvesting reservoirs. By identifying sites where improvements could be built, this work effectively expanded past studies showing the provinces could benefit from improvement to water resources infrastructure $[26,56]$. Specifically, Cambodian officials can cross-reference our suitability model with the HydroSHEDs database. They can then run a hydrologic analysis similar to this paper to 
refine reservoir suitability further. While this study helps identify suitable locations where improvements could be made, around $46 \%$ of the country has low suitability or worse for water harvesting. These areas still suffer from droughts and floods, and future studies will need to evaluate other ways water resources infrastructure can be improved here.

Globally, this model development method can also be applied to other water-scarce countries to improve surface water storage. Between 2010 and 2025, water demand in developing countries is expected to increase by $50 \%$ [57]. Thus, it is vital to develop approaches to improve water resources management and storage worldwide. The method used in this study can be adapted to other countries by modifying the criteria to be locationspecific and then by subsequently surveying local experts. The result would be a water harvesting suitability model that accurately reflects local conditions and priorities. Local stakeholders could then utilize the model to make targeted improvements to their water resources infrastructure.

Theoretically, this research demonstrates how AHP theory can improve project decisionmaking for disaster infrastructure in climate-vulnerable countries. Deciding where to construct infrastructure is a complicated process that requires managers to evaluate a multitude of technical criteria, such as hydrologic geospatial data. To avoid reliability issues, infrastructure managers need to incorporate multiple experts (e.g., civil engineers, hydrologists, urban planners) to truly develop a more accurate decision-model However, in countries with limited technical capacity, there has been limited work evaluating methods to synthesize this knowledge $[4,58,59]$. We theorized that the AHP theory could fill this knowledge gap to improve decision-making processes involving multiple technical criteria and expert opinions. The consistency index of 0.01 indicated that the data were consistent and that the method effectively synthesized both Cambodian and American expertise. AHP provides a mechanism to incorporate the expertise and decisions from multiple experts holistically. This contribution improves our knowledge of project decision-making by delivering reliable results based on multiple expertise.

\section{Conclusions}

As the climate continues to change in Cambodia, this research comes at a critical time. There is a need to improve Cambodia's water resources infrastructure to help mitigate the impacts of droughts and floods. This research argued that water harvesting is one approach that could be used to meet this objective. Through a combination of geospatial analysis and analytical hierarchy process, suitable and non-suitable sites for water harvesting were identified across Cambodia. This objective was accomplished through three main steps. First, water harvesting suitability was decomposed into five main engineering criteria: slope gradient, geologic porosity, soil drainage, land cover, and precipitation. Next, 31 local experts were surveyed to determine the weights of the different criteria. Finally, the expert opinions were synthesized to create a suitability model in GIS. The model showed that $19 \%$ of Cambodian land has high suitability, and about 13\% of the land has the best suitability.

Ultimately, this work has significant practical and theoretical contributions. Cambodian officials can practically use this model to identify sites that can be utilized for water harvesting reservoirs. Installing such reservoirs has the potential to improve community resiliency against droughts and floods. Theoretically, the study helps address the current lack of water resources studies in Cambodia. In particular, it shows how the AHP method can be expanded to help improve infrastructure in Cambodia. Building off this model and contributions, future studies should work with the identified sites to understand the social and governance networks to determine if they would accept and benefit from water harvesting reservoirs. Community participation and acceptance are critical to successfully managing water resources in Cambodia, and future studies should evaluate how technical feasibility and community participation can be integrated [3,4]. In addition, more work is needed to understand the impact diverted water would have on Cambodia's river systems and the greater Mekong watershed. 
Supplementary Materials: The following are available online at https://www.mdpi.com/2073-444 1/13/3/367/s1, Questionnaire.

Author Contributions: M.W. contributed to the conceptualization, formal analysis, investigation, methodology, and writing the original draft. C.P. contributed to the funding acquisition, research supervision, results validation, manuscript reviewing, and manuscript editing. M.P. contributed to the spatial analysis, research supervision, results validation, manuscript reviewing, and manuscript editing. All authors have read and agreed to the published version of the manuscript.

Funding: This research received no external funding.

Institutional Review Board Statement: The study was conducted according to the guidelines of the Iowa State University, and approved by the Institutional Review Board (or Ethics Committee) of Iowa State University (Protocol code 19-255, Initial Approval 24 May 2019).

Informed Consent Statement: Informed consent was obtained from all subjects involved in the study.

Data Availability Statement: Some or all data, models, or code generated or used during the study are proprietary or confidential in nature and may only be provided with restrictions. The survey data is protected by an IRB protocol. The questionnaire used has been attached as a Supplementary Materials.

Acknowledgments: This product manuscript incorporates data from the HydroSHEDS database which is (C) World Wildlife Fund, Inc. (2006-2013) and has been used herein under license. WWF has not evaluated the data as altered and incorporated within the manuscript, and therefore gives no warranty regarding its accuracy, completeness, currency or suitability for any particular purpose. Portions of the HydroSHEDS database incorporate data which are the intellectual property rights of (C) USGS (2006-2008), NASA (2000-2005), ESRI (1992-1998), CIAT (2004-2006), UNEP-WCMC (1993), WWF (2004), Commonwealth of Australia (2007), and Her Royal Majesty and the British Crown and are used under license. The HydroSHEDS database and more information are available at http:/ / www.hydrosheds.org.

Conflicts of Interest: The authors declare no conflict of interest.

\section{References}

1. Asthana, A.N. Is Participatory Water Management Effective? Evidence from Cambodia. Water Policy 2010, 12, 149-164. [CrossRef]

2. IDMC Cambodia Internal Displacement. Available online: https:/ /www.internal-displacement.org/countries/cambodia (accessed on 23 June 2020).

3. Mang, G. Moving Blindly towards Integrated Water Resources Management? Challenges and Constraints Facing Cambodia's New Water Law. Asia Pac. J. Environ. Law 2009, 12, 21.

4. Sithirith, M. Water Governance in Cambodia: From Centralized Water Governance to Farmer Water User Community. Resources 2017, 6, 44. [CrossRef]

5. Ministry of Environment. Synthesis Report on Vulnerability and Adaptation Assessment for Key Sectors Including Strategic and Operational Recommendations; Ministry of Environment: Phnom Penh, Cambodia, 2013.

6. Studer, R.; Liniger, H. Water Harvesting: Guidelines to Good Practice; Center for Development and Environment: Bern, Switzerland, 2013.

7. Critchley, W.; Siegert, K. A Manual for The Design and Construction of Water-Harvesting Schemes for Plant Production; United Nations Food and Agriculture Organization: New York, NY, USA, 1992.

8. Al-shabeeb, A.R. The Use of AHP within GIS in Selecting Potential Sites for Water Harvesting Sites in the Azraq Basin-Jordan. JGIS 2016, 8, 73-88. [CrossRef]

9. Aravinda, P.T.; Balakrishna, H.B.; Jayaramu, K.C. Identification of Potential Sites for Detention Ponds along the Vrishabhavathi River. Aquat. Procedia 2015, 4, 585-592. [CrossRef]

10. Pawattana, C.; Tripathi, N.K. Analytical Hierarchical Process (AHP)-Based Flood Water Retention Planning in Thailand. GISci. Remote Sens. 2008, 45, 343-355. [CrossRef]

11. Nguyen, H.-Q.; Radhakrishnan, M.; Quang, C.N.X. Urban Retention Basin in a Developing City: From Theoretical Effectiveness to Practical Feasibility. In Proceedings of the 13th International Conference on Urban Drainage, Kuching, Malaysia, 7-12 September 2014.

12. Saha, A.; Patil, M.; Karwariya, S.; Pingale, S.M.; Azmi, S.; Goyal, V.C.; Rathore, D.S. Identification of Potential Sites for Water Harvesting Structures Using Geospatial Techniques and Multi-Criteria Decision Analysis. Int. Arch. Photogramm. Remote Sens. Spatial Inf. Sci. 2018, 5, 329-334. [CrossRef]

13. Wu, R.-S.; Molina, G.L.L.; Hussain, F. Optimal Sites Identification for Rainwater Harvesting in Northeastern Guatemala by Analytical Hierarchy Process. Water Resour. Manag. 2018, 32, 4139-4153. [CrossRef] 
14. Day, M.B.; Hodell, D.A.; Brenner, M.; Chapman, H.J.; Curtis, J.H.; Kenney, W.F.; Kolata, A.L.; Peterson, L.C. Paleoenvironmental History of the West Baray, Angkor (Cambodia). Proc. Natl. Acad. Sci. USA 2012, 109, 1046-1051. [CrossRef]

15. Penny, D.; Pottier, C.; Kummu, M.; Fletcher, R.; Zoppi, U.; Barbetti, M.; Tous, S. Hydrological History of the West Baray, Angkor, Revealed through Palynological Analysis of Sediments from the West Mebon. Bull. Ec. Française Extrême Orient 2005, 92, 497-521. [CrossRef]

16. Someth, P.; Kubo, N.; Tanji, H. A Combined Technique of Floodplain Storage and Reservoir Irrigation for Paddy Rice Cultivation. Paddy Water Environ. 2007, 5, 101-112. [CrossRef]

17. Chhuon, K.; Herrera, E.; Nadaoka, K. Application of Integrated Hydrologic and River Basin Management Modeling for the Optimal Development of a Multi-Purpose Reservoir Project. Water Resour. Manag. 2016, 30, 3143-3157. [CrossRef]

18. Dano, U.; Balogun, A.-L.; Matori, A.-N.; Wan Yusouf, K.; Abubakar, I.; Said Mohamed, M.; Aina, Y.; Pradhan, B. Flood Susceptibility Mapping Using GIS-Based Analytic Network Process: A Case Study of Perlis, Malaysia. Water 2019, 11, 615. [CrossRef]

19. Oswald Beiler Michelle, R. Treat Christian Integrating GIS and AHP to Prioritize Transportation Infrastructure Using Sustainability Metrics. J. Infrastruct. Syst. 2015, 21, 04014053. [CrossRef]

20. Romanelli, J.P.; Silva, L.G.M.; Horta, A.; Picoli, R.A. Site Selection for Hydropower Development: A GIS-Based Framework to Improve Planning in Brazil. J. Environ. Eng. 2018, 144, 04018051. [CrossRef]

21. Peou, H.; Natarajan, I.; Tianhua, H.; Philippe, D. From Conservation to Sustainable Development-A Case Study of Angkor World Heritage Site, Cambodia. J. Environ. Sci. Eng. A 2016, 5, 141-155. [CrossRef]

22. Peou, H. Sacred Water: Rediscovering the Ancient Hydraulic System of Angkor and Traditional Knowledge of Water Management and Engineering Systems. Int. J. Intang. Herritage 2014, 9, 9.

23. Saaty, T.L. The Analytic Hierarchy Process: Planning, Priority Setting, Resource Allocation; McGraw-Hill International Book Co: New York, NY, USA, 1980; ISBN 978-0-07-054371-3.

24. Pavelic, P.; Srisuk, K.; Saraphirom, P.; Nadee, S.; Pholkern, K.; Chusanathas, S.; Munyou, S.; Tangsutthinon, T.; Intarasut, T.; Smakhtin, V. Balancing-out Floods and Droughts: Opportunities to Utilize Floodwater Harvesting and Groundwater Storage for Agricultural Development in Thailand. J. Hydrol. 2012, 470-471, 55-64. [CrossRef]

25. Sam, S.; Shinogi, Y. Performance Assessment of Farmer Water User Community: A Case Study in Stung Chinit Irrigation System, Cambodia. Paddy Water Environ. 2015, 13, 19-27. [CrossRef]

26. Räsänen, T.A.; Joffre, O.M.; Paradis, S.; Tran, T.C.; Keskinen, M.; Kummu, M. Model-Based Assessment of Water, Food, and Energy Trade-Offs in a Cascade of Multipurpose Reservoirs: Case Study of the Sesan Tributary of the Mekong River. J. Water Resour. Plan. Manag. 2015, 141, 05014007. [CrossRef]

27. Clausen, T.J. Technical Annex on Integrated Water Resources Management (IWRM); Asian Development Bank: Phnom Penh, Cambodia, 2009; p. 53.

28. Erban, L.E.; Gorelick, S.M. Closing the Irrigation Deficit in Cambodia: Implications for Transboundary Impacts on Groundwater and Mekong River Flow. J. Hydrol. 2016, 535, 85-92. [CrossRef]

29. Mu, E.; Pereyra-Rojas, M. Practical Decision Making; SpringerBriefs in Operations Research, Springer International Publishing: Cham, Switzerland, 2017; ISBN 978-3-319-33860-6.

30. Food and Agricultural Organization. World Reference Base for Soil Resources 2014: International Soil Classification System for Naming Soils and Creating Legends for Soil Maps; FAO: Rome, Italy, 2014; ISBN 978-92-5-108369-7.

31. Gleeson, T.; Moosdorf, N.; Hartmann, J.; van Beek, P.H.L. A Glimpse beneath Earth's Surface: GLobal HYdrogeology MaPS (GLHYMPS) of Permeability and Porosity. Geophys. Res. Lett. 2014. [CrossRef]

32. Climate Hazards Group UCSB. Cambodia Historic Average Rainfall; CHG: Santa Barabara, CA, USA, 2014.

33. Save Cambodia's Wildlife USGS. Geographical Relief of Cambodia. In Atlas of Cambodia; SCW: Phnom Penh, Cambodia, 2013.

34. Asian Disaster Preparedness Center SERVIR-Mekong. Land Cover in Cambodia (2012-2016); ADPC: Yangon, Myanmar, 2018.

35. Studer, R.M.; Liniger, H. Water Harvesting: Guidelines to Good Practice; Centre for Development and Environment: Rome, Italy, 2018; ISBN 978-3-905835-35-9.

36. Fischer, G.; van Velthuizen, H.; Shah, M.; Nachtergaele, F. Global Agro-Ecological Assessment for Agriculture in the 21st Century: Methodology and Results; Food and Agriculture Organization of the United Nations: Rome, Italy, 2002; p. 155.

37. Natural Resoures Conservation Service. Technical Release 210-60 Earth Dams and Reservoirs; NRCS: Fort Worth, TX, USA, 2019.

38. Funk, C.; Peterson, P.; Landsfeld, M.; Pedreros, D.; Verdin, J.; Shukla, S.; Husak, G.; Rowland, J.; Harrison, L.; Hoell, A.; et al. The Climate Hazards Infrared Precipitation with Stations-A New Environmental Record for Monitoring Extremes. Sci. Data 2015, 2, 150066. [CrossRef] [PubMed]

39. Jenks, G.F. Optimal Data Classification for Choropleth Maps; Department of Geographiy, University of Kansas: Lawrence, KS, USA, 1977.

40. Food and Agriculture Organization of the United Nations. Country Profile-Cambodia; FAO: Rome, Italy, 2011.

41. Forman, E.; Peniwati, K. Aggregating Individual Judgments and Priorities with the Analytic Hierarchy Process. Eur. J. Oper. Res. 1998, 108, 165-169. [CrossRef]

42. Saaty, T.L.; Vargas, L.G. Inconsistency and Rank Preservation. J. Math. Psychol. 1984, 28, 205-214. [CrossRef]

43. Malczewski, J. GIS and Multicriteria Decision Analysis; John Wiley \& Sons: New York, NY, USA, 1999; ISBN 978-0-471-32944-2. 
44. Government of Cambodia. Natural Protected Areas in Cambodia (1993-2018); Government of Cambodia: Phnom Penh, Cambodia, 2015.

45. Cambodia Mine Action Center. Ten Years Achievement and Perspective; CMAC: Phnom Penh, Cambodia, 2010.

46. Office for the Coordination of Humanitarian Affairs. Baseline Survey on Mine/ERW (2009-2014); OCHA: Phnom Penh, Cambodia, 2014.

47. Jaafar, H.H.; Ahmad, F.A.; El Beyrouthy, N. GCN250, New Global Gridded Curve Numbers for Hydrologic Modeling and Design. Sci. Data 2019, 6, 145. [CrossRef]

48. Natural Resoures Conservation Service. Small Watershed Hydrology; NRCS: Washington, DC, USA, 2009.

49. Lehner, B. HydroSHEDS Technical Documentation; World Wildlife Fund: Washington, DC, USA, 2013; p. 26.

50. Cambodia Development Watch. Boeung Kak Lake Lease Agreement; CDW: Phnom Penh, Cambodia, 2007.

51. World Bank Group. Urban Development in Phnom Penh; World Bank Group: Phnom Penh, Cambodia, 2017.

52. Yabuta, J. The Study on Integrated Master Plan for Suistainable Development of Siem Reap/Angkor Town in the Kingdom of Cambodia; International Development Center of Japan: Toyko, Japan, 2006.

53. Le, T.V.H.; Nguyen, H.N.; Wolanski, E.; Tran, T.C.; Haruyama, S. The Combined Impact on the Flooding in Vietnam's Mekong River Delta of Local Man-Made Structures, Sea Level Rise, and Dams Upstream in the River Catchment. Estuarine Coast. Shelf Sci. 2007, 71, 110-116. [CrossRef]

54. Buakhao, W.; Kangrang, A. DEM Resolution Impact on the Estimation of the Physical Characteristics of Watersheds by Using SWAT. Available online: https:/ / www.hindawi.com/journals/ace/2016/8180158/ (accessed on 13 September 2020).

55. Hoang, L.; Mukundan, R.; Moore, K.E.B.; Owens, E.M.; Steenhuis, T.S. The Effect of Input Data Resolution and Complexity on the Uncertainty of Hydrological Predictions in a Humid Vegetated Watershed. Hydrol. Earth Syst. Sci. 2018, 22, 5947-5965. [CrossRef]

56. Center for Excellence in Disaster Management \& Humanitarian Assistance. Cambodia Disaster Management Reference Handbook; CEDMHA: Ford Island, HI, USA, 2017.

57. Pengra, B. A Glass Half Empty:Regions at Risk Due to Groundwater Depletion. UN Environ. Program 2012, 2, 117-127. [CrossRef]

58. Bowen, K.; Miller, F.; Dany, V.; Graham, S. The Relevance of a Coproductive Capacity Framework to Climate Change Adaptation: Investigating the Health and Water Sectors in Cambodia. Ecol. Soc. 2015, 20. [CrossRef]

59. Liu, J.; Xu, Z.; Chen, F.; Chen, F.; Zhang, L. Flood Hazard Mapping and Assessment on the Angkor World Heritage Site, Cambodia. Remote Sens. 2019, 11, 98. [CrossRef] 